\title{
A study of Serum Steroid Hormones Concentrations Of Pregnant Cows.
}

\author{
AL-Anbaky , K. I. H. \\ Dept .Surg. and Obst. - College of. Vet. Med. - Bagdad University- \\ Baghdad -Iraq.
}

\section{Summary}

The objective of present work is to estimated peripheral blood serum concentrations of pregnancy hormones, oestradiol, progesterone and testosterone, in cows . For this purpose 24 Frezain- Holstein cows at different stages of pregnancy the blood samples were taken from jugular veins. The serum were separated and frozen at $-20 \mathrm{c}$ until analysis. The serum hormones were measured by a specific ELISA technique (ELISA Linear Multi Reader). The data were represented Mean \pm S.D. Progesterone was high during pregnancy reaching a maximum of $91.94 \pm 26.09 \mathrm{ng} / \mathrm{ml}$ during last thirds (6-8 months) of pregnancy, but was below $9.12 \pm 2.41 \mathrm{ng} / \mathrm{ml}$ for several months during the pregnancy. Oestradiol levels varied from $9.0 \pm 2.89 \mathrm{pg} / \mathrm{ml}$ in the first thirds of pregnancy to $282.6 \pm 48.514 \mathrm{pg} / \mathrm{ml}$ during the last month of gestation. While testosterone hormone level was low $0.32 \pm 0.12 \mathrm{ng} / \mathrm{ml}$ during pregnancy. The result indicated that the major sources of hormones appeared to be the 0vary (corpus luteum ) and the uterus (placenta). The ovarian contribution was greater during the first - thirds of pregnancy than later, whereas that made by the placenta was higher during the last thirds of pregnancy.

$$
\begin{aligned}
& \text { دراسة قياس مستوى الهرمونات الستيرويدية في مصل الابقار الحوامل } \\
& \text { فرع الجر احة و التوليد ـ كلية الطبل ابراهيم حسين البيطري - جأمعة بغداد ــبغداد ـالعراق }
\end{aligned}
$$

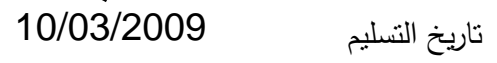

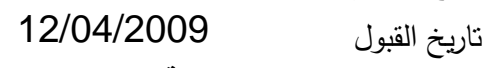

$$
\begin{aligned}
& \text { الخلاصة } \\
& \text { الهدف من الدراسة قياس مستو هرمونات الدم - البروجسترون الاستروجين والتيستيستيرون في دم الابقار الحوامل سحب الدم الوريدي }
\end{aligned}
$$

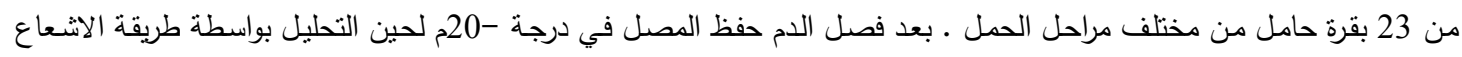

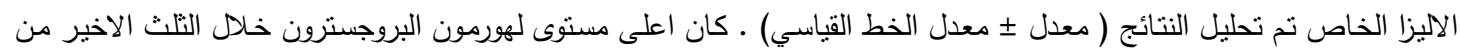

$$
\begin{aligned}
& \text { الحمل } 6 \text { - } 8 \text { الشهر وكان } 26.09 \text { ـ } 91.94 \text { نانوغرام / مليليتر الواحد بينما في الثلث الاول من الحمل كان مستو } 2.41 \text { ـ } 2.12
\end{aligned}
$$

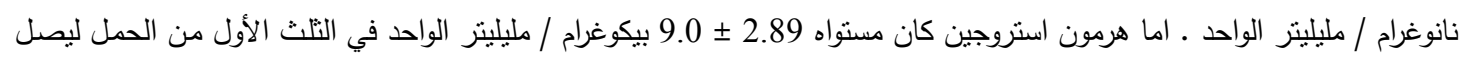

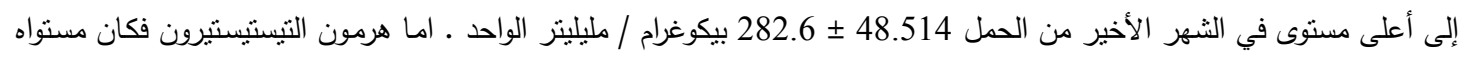

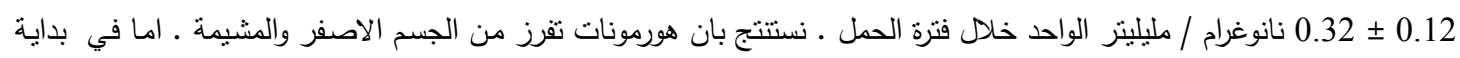

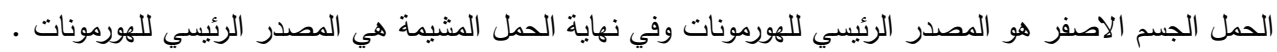

The cow occupies an intermediate position between the sheep and goat in term of the mechanism by which the progesterone requirements of pregnancy. In intact cows during the pregnancy the progesterone concentration in ovarian is 50- 100 time greater than that in the uterine or in the jugular vein $(1+2)$. In pregnant cow excretes increasing amounts of estradiol -17 alpha, estrone and estradiol 17 beta and placenta appears to be the major site of estrogen production ( 3). (4) reported that testosterone is converted to estrogen in the basement membrane of theca cells in the cows. The role of testosterone in female genital organ remains controversial and poorly understood (5). Present work is design to estimate the serum level of progesterone, testosterone and estradiol at different stages of pregnant cows.

\section{Materials and methods}


Twenty four (24) a adult Friesian- Holstein cows of various stages of gestation were used in present work .The animals were born in Iraq and had at least one birth and naturally inseminated. The cows were housed indoors under natural lighting and fed ahay- concentration ratio to requirement . blood samples were taken from jugular vein and centrifuged in EDTA tubes (Ethylene diamine tertra acetic acid ). The serum was aliquated and stored at $-20 \mathrm{c}$ until assay. The progesterone, estradiol and testosterone hormones were measured by highly specific enzyme- linked immunosorbent assay ELISA using (ELISA) kids (IBL- Hamburg. Com) and (ELISA Linear multi reader ). All the measurement were present in; ng (nanogram) for progesterone, testosterone levels; and pg (pictogram) for estradiollevels.

Statistical analysis was calculated by Student $\mathrm{t}$-test differences between values were considered significant at $\mathrm{p}<0.05$ and higyly significant at $\mathrm{p}<0.01$ (6).

Results

Steroid hormones levels during different stages of pregnancy are present in Table (Table 1).

$$
\begin{gathered}
\text { Table (1): Serum progesterone } \mathrm{ng} / \mathrm{ml}, \text { Testosterone } \mathrm{ng} / \mathrm{ml} \text { and } \\
\text { Estrogen pg/ml Concentration During Pregnancy in cow } . \mathrm{M} \pm \text { S.D. } \\
\mathrm{n}=36
\end{gathered}
$$

\begin{tabular}{|l|l|l|l|}
\hline $\begin{array}{l}\text { Months in to } \\
\text { pregnancy }\end{array}$ & Estradiol & Testosterone & Brogesterone \\
\hline $\begin{array}{l}\text { Up to } 3 \\
\text { months }\end{array}$ & $9.2 \pm 2.89 \mathrm{a}$ & & $1.673 \pm 0.707 \mathrm{a}$ \\
\hline $3-5$ months & $48.2 \pm 10.685 \mathrm{~b}$ & $0.32 \pm 0.117 \mathrm{a}$ & $9.117 \pm 2.411 \mathrm{~b}$ \\
\hline $5-8$ months & $208.92 \pm 42.62 \mathrm{c}$ & & $91.94 \pm 26.090 \mathrm{c}$ \\
\hline 8 end & $282.6 \pm 48.514 \mathrm{~d}$ & $0.541 \pm 0.304 \mathrm{~b}$ & $1.26 \pm 713 \mathrm{aa}$ \\
\hline
\end{tabular}

Different letter mean significant at $<\mathrm{p} 0.05, \mathrm{p} 0.01$ or $\mathrm{p}<0.001$

The hormones assay were pooled on a monthly basis. The table1 give progesterone, estrogen and testosterone hormones results in 24 adults Friesian - Holstein cows which were showing psychic estrous and subsequently became pregnant. Table 1. reveled that the serum progesterone levels were showed significantly steadily increased during pregnancy and declined sharply in the last few days before birth to reach the level almost similar that of the first trimester $1.26 \pm 0.713 \mathrm{ng} / \mathrm{ml}$. Blood estrogen concentration increasing solely to an average of $9 \pm 2.89 \mathrm{pg} / \mathrm{ml}$ at first 3 months prepartum and then more steeply to $208 \pm 42.62 \mathrm{pg} / \mathrm{ml} \mathrm{P}<0.01$ significantly from first to second and third trimester to reach the highest concentrations during the last month of gestation. The Highest individual value was $336 \mathrm{pg} / \mathrm{ml}(206-336 \mathrm{ng} / \mathrm{ml})$. peripheral serum testosterone hormone slightly increase during pregnancy(Table 1).

\section{Discussion}

Progesterone level is used to select pregnant cow. The rationale for this test is that females are pregnant Britt, (7) reported luteum persist and progesterone concentrations remain high. The plasma progesterone concentrations, laboratory diagnoses of pregnancy, and results of pregnancy determination based on non-return to estrus and on rectal palpation (8).Cows with a plasma progesterone concentration exceeding $2.5 \mathrm{ng} / \mathrm{ml}$ at a single determination between days 19 and 22 were classed as pregnant. The accuracy of a laboratory diagnosis of pregnancy was $85 \%$ when compared to the results obtained by rectal palpation 6 to 7 weeks after insemination (9).

The plasma progesterone value for pregnant cows were similar to those previously reported by 1011 And did not differ from found in cycling cows during the height of the luteal phase (day10 to 17, (9). the data reported here is with agreement with finding of Short2007 which reported that blood progesterone increased from 32- 256 days of pregnancy and decreased rapidly just before calving. 
Estrone sulfate, conjugated astrogen, is the product of the fetal placental unit and has been used to dignose pregnancy in ruminant (12). Increasing estrogen activity in near term supports the theory that parturition may be initiated by decreasing progesterone and increasing estrogen on assumption that uterine contractility rifles estrogen levels(13). Estrogen and testosterone accelerate blood flow to uterus (14) and testosterone not only the immediate precursors of estrogen during pregnancy (15). While, the role of androgen in female genital organ remain controversial and poorly understood (16).

\section{References}

1- Thoburn, G.D. and Challis, J.R.G. (1985). Endocrinology of Parturition. In: Scientific Foundations of Veterinary Medicine. Pup 2th edts PP32-39.

2- Roman, J. E. (2007). Pregnancy Diagnosis In Cattle. Review. PDF Creator- PDF 4Free v2.0 http:// www. Pdf4free.com. Pp, 1-7.

3- Aniworth , L. and Ryan ,K.J. ( 1966). Steroid hormone transformation by endocrine organs from pregnant mammalians . 1. Estrogen biosynthesis by mammalian placenta preparation in vitro. Endocrinology 79. 875- 890.

4- Labrif, F., Belanqer, A. Cusan, L. and Candas, B.(1997). Physiology changes in dehydroepiandrosterone are not reflected by serum levels of active androgen and estrogen but of their metabolism . J.Clini.Endocrinol. Meta .82, 2403 - 2409.

5- Tanzer,B., Turk, G. and Gur, S. (2007). Effect of clitoral massage on levels of estradiol, testosterone, dehydroepiandrosterone sulphate and pregnancy rate in cows. Veterina Rski Arhiv 77 (1), 59-67.

6- Daniel, W.W.(1988). Multiple regression and correlation in : Biostatistics. A foundation of Analysis in the health Science. Daneal.ww (edt).

7- Britt, J.H.(1995). The relationship between postpartum estrous, estrous cycle length, and early embryonic death. Cattle Prac.9., 85-88.

8- Skemesh,M. Ayalon,and .Lindmer, H.R.(2009). Early pregnancy diagnosis based upon plasma progesterone levels in cow and ewe. Amer.Soc. Ani. Sci. 726-729. w.w.w. assas.org.

9- Shemesh, M., Ayalon ,N., and Shalev, E.Nerya, A. Schindler, H. and

Milgur, F.(1978) . Milk and blood Progesterone measurement in dairy cow: correlation with estrous and pregnancy determination. Theriogenology .9;343-353.

10 Donaldson, L.E., Basset, J.M. and Thorburn.G.D. (1970). Peripheral progesterone concentration of cows during puberty, estrous cycle pregnancy and lactation, and the effects of under nutrition or exogenous oxytocin on on progesterone concentrations. J.Endon.,48,599-609.

11- Robinson, R.Baker.R.D. Anastassiadis,P.A. and Common,R.H. (1970). Estrogen concentrations in the peripheral blood of pregnancy cows. J. Dairy Sci.,53 (11); 1592-1595.

12- Mohamed, A.R., Noakes, D.E., Booth, J.M. and Chaplin, V.(1987). Plasma estrogen sulphate and progesterone concentrations in cows and ewes associated with fetal and abortion. Br. Vet. J; 143,238245.

13- Hirako,M.. Takahashi , T. and Domeki , I. ( 2002). Peripheral chanhes in estrogen sulfate concentration during the first trimester of gestation in Catlle : comparison uncon jngated estrogen and relation ship to fetal membrane, therio genlogy . $57: 1939$ - 1947 .

14- Min, K.R., Munarriz, N., kim,N., Goldstein , I.. and Traish, A.(2002). Effects of ovariectomy and estrogen and androgen treatment on sidenafil-mediated changes in female genital blood flow and vaginal lubrication in the animal model. Am.J.Obst.Gynecol.187,1370-1376.

15- Park,K.., Ahn,K., Lee,S., Ryu,S., Park T., Azodozol (2001). Decreased circulating levels of estrogen alter vaginal and clitoral blood flow and structure in the rabbit. Int J. Impot. RES. 13, 116-124.

16- Carlsen, S.M., Jacobsen , G., and Romundstad, P., (2006). Maternal testosterone levels during pregnancy are associated with offspring size at birth. 